\title{
Diário de Campo de um indigenista missionário: Vicente Cañas (1939-1987)
}

\author{
A Field Diary of indigenous missionary: \\ Vicente Cañas (1939-1987)
}

Aloir Pacini SJ *

\section{Resumo}

O Irmão Vicente Cañas (1939-1987) escreveu um Diário de Campo no tempo em que viveu com os índios Enawene Nawe, um grupo étnico nativo do norte do Mato Grosso (Brasil) com o qual ele mesmo estabeleceu os primeiros contatos e procurou acompanhá-los desde este dia 28/07/1974 até o dia de sua morte trágica a mando dos fazendeiros. O fato dele escrever um Diário relatando tudo o que aconteceu neste ambiente indígena é importante para recuperar dados de grande validade etnográfica e para mostrar a luta de um Irmão jesuíta não muito confortável com as letras. No entanto, o mais valioso é que este esforço para deixar registrado estas descrições indicam que o jesuíta sabia da importância destes registros para os índios. Por outro lado, este diário mostra também como este jesuíta viveu inculturado neste meio, pois sabia que sua maneira de agir marcaria para sempre o futuro deste grupo étnico que sofria os avanços de frentes agropecuárias.

Palavras Chaves: Enawenê Nawê; Diário de Campo; indigenista missionário.

\begin{abstract}
Brother Vicente Cañas (1939-1987) wrote a Field Diary in the time in which he lived with the Indians Enawene Nawe, a native ethnic group of northern Mato Grosso (Brazil) with which he established the first contacts and tried to follow since the day 07/28/1974 until his tragic death at the behest of the farmers. The fact that he keep a diary recounting everything that happened in this indigenous environment is important to recover data of great

\footnotetext{
* Aloir Pacini teve uma formação apurada enquanto jesuíta e se dedicou à antropologia no Mestrado (PPGAS UFRJ) e no Doutorado (PPGAS UFRGS). Possui um foco na etnologia indígena a partir de onde observa o processo colonizador. Atuou fortemente junto ao Museu Rondon e atualmente é chefe do Departamento de Antropologia da UFMT.
}

130 Alois Pacini SJ. Diário de campo de um indigenista missionário. V. Cañas (1939-1987)... 130-149 
ethnographic validity and to show the struggle of a Jesuit Brother not very comfortable with the letters. However, the most valuable is the effort to record that he knew these descriptions are most important for the Indians. On the other hand, this Field Diary shows how this Jesuit lived inculturated in this environment, knowing that their ways would mark forever the future of this ethnic group that suffered the advances of ranchers.

Key words: Enawene Nawe; Field Diary; indigenous missionary.

Recibido: 12 de noviembre de 2015

Evaluado: 20 de diciembre de 2015 


\section{Introdução}

Não tive acesso a todos os originais do Diário do Irmão jesuíta Vicente Cañas, contudo, as informações que adquiri são que a parte datilografada que temos foi feita por Darci Luiz Pivetta, um trabalho dedicado, com correções a lápis feita pelo Pe. Iasi Júnior. Em todo caso, o transcritor teve critérios explícitos para o grande feito: ser o mais fiel possível aos originais; busca de conciliação da elaboração de forma para alcançar a compreensão do leitor e, em caso de dúvida, recorrer aos dez anos de convivência e conversações com Cañas para interpretações. Acrescentei o critério da uniformidade da escrita, dado que principalmente as palavras na língua indígena na época estavam nas suas primeiras tentativas de sistematização e Cañas foi o primeiro a aprendê-la entre os que se aproximaram desta etnia. Outra mudança é a escrita dos nomes das pessoas e dos rituais em letras maiúsculas que foram mudados para a regra da letra inicial maiúscula e o restante em minúsculo. Nos manuscritos era necessária a letra maiúscula para evitar confusão na grafia, mas agora, digitalizado, não precisa mais.

Alguns dados importantes ainda precisam ser escritos para compreender o labor fenomenal que foi esta iniciativa de Cañas em escrever um diário. Foi o próprio Pivetta o incentivador deste trabalho quando Cañas decidiu ir no final do ano de 1975 morar com os Enawenê Nawê ${ }^{1}$ participar ativamente do seu dia a dia. Pivetta informou que leu com Cañas a introdução ao livro de Malinowski (Argonautas do Pacífico Ocidental) para convencê-lo que era necessário procurar um lugar para morar um pouco longe da aldeia. $\mathrm{O}$ local escolhido para seu barraco foi logo abaixo do Caixão de Pedra, no rio Juruena onde este rio passa de cerca de 800 metros de largura para cerca de 12 metros. Junto deste "barraco", Vicente Cañas foi martirizado. A outra informação importante foi o registro dos acontecimentos em diário de campo, pois, insistia Pivetta, o acesso aos acontecimentos por Cañas era privilegiado. Mas este afirmou que não o faria, pois tinha pouco trato com as letras. Contudo, quando Pivetta foi até o barraco de Vicente com o Pe. Adalberto Holanda Pereira, três anos depois, Cañas lhe mostrou o diário. O resultado desta dedicação de Cañas produziu 32 cadernos, cerca de 2.000 páginas. Contudo, vou dar importância especial aos primeiros escritos do Diário porque ali se elaboram os momentos mais originais do missionário indigenista.

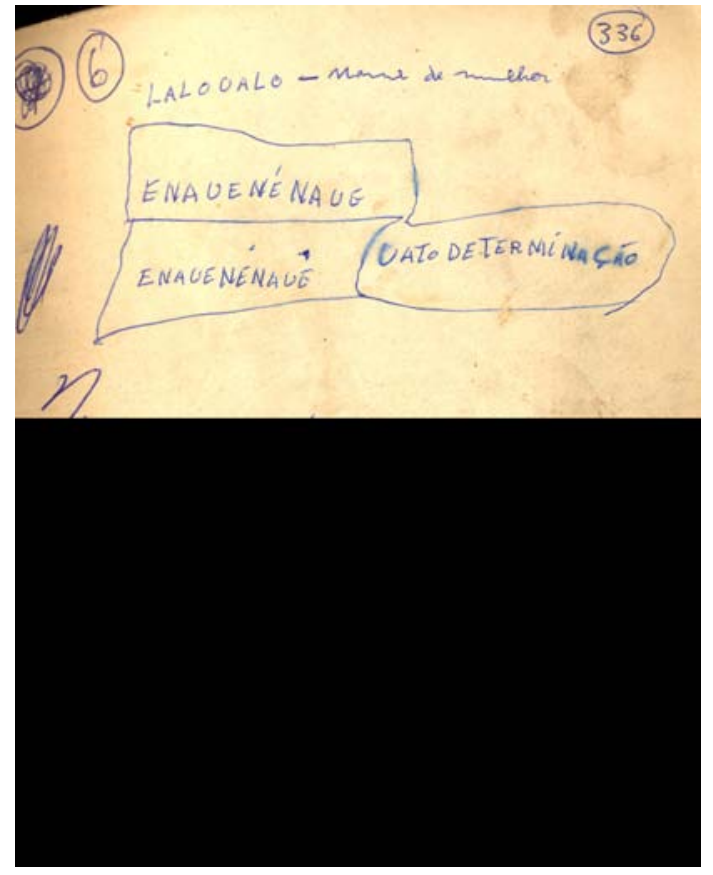

Elas iniciam em 01/07/1977, considerado o $15^{\circ}$ contato com os Enawenê Nawê. Esta parte do diário começa solene mencionando o ritual intenso, no qual todos

\footnotetext{
${ }^{1}$ A autodenominação encontrada no diário de Vicente Cañas tem uma pequena mudança na forma como passou a ser escrito nas publicações, por isso vamos usar como está sendo divulgado a partir dos escritos de Bartomeu Melià. No início ainda se nomeava esta etnia pelo etnônimo Salumã, mas tratava-se de um nome pessoal ou um ritual desta etnia e não da autodenominação étnica.
} 
participavam:

"Durante quase uma lua, tiveram ceirohi - flauta de cinco canos e várias de outro tipo. Todos esses dias de madrugada (2h) começava parando ao clarear o dia. Pelas 15 horas começava de novo. Vai até o anoitecer. Começava no terreiro e dentro das casas, todos os homens participam."

Certo é que Cañas se superou em muito nesta atividade da escrita, pois não era seu perfil de homem prático, ficar envolto em teorias ou mesmo em escritas. Contudo, sabendo da importância para os Enawenê Nawê desta atividade, a ele se dedicou com diligência. Por isso vamos trazer algumas partes deste trabalho valioso à baila para que se possa apreciar com detalhes este trabalho que não tinha resultados imediatos de forma alguma.

Apesar da presença discreta de Cañas, este tinha consciência de que sua simples presença interferia na vida dos nativos. Contudo, isso não o deixava relaxado em relação a deixar que a autodeterminação dos Enawenê Nawê chegasse ao máximo possível. Nos dias seguintes desta $15^{\mathrm{a}}$ chegada na aldeia, alguns saem para pescar batendo timbó, mas os que ficam continuam tocando e cantando. As mulheres participam de forma diferente, quase todos os dias arrancam mandioca e preparam a chicha (ketera) de água de mandioca, milho, batata, tudo fervido.

"Toda a pescaria que pescam, peixe grande é repartido comunitariamente. Hoje das duas de madrugada até 20 h30 sem parar tocaram e dançaram, primeiro no terreno e depois dentro das casas, quando passam todo o dia dançando. É o fim do ritual, todas as cerimônias, pintados e enfeitados com os seus penachos e palha de buriti. Algumas crianças estão com febre, algumas saem para pescar. Duas meninas participaram toda a tarde da dança. Aparentam sete anos. Estão enfeitadas de colares e pintadas de urucum" (05/07/77).

A observação a respeito das doenças é constante no Diário, o que indica um foco de seu trabalho, pois Cañas atua decisivamente: "faço o tratamento". Pivetta falou da perspicácia e rapidez com que aprendeu odontologia com o Irmão Christ e atuou também nesta área arrancando seus próprios dentes e fazendo sua própria prótese dentária enquanto estava com os Enawenê Nawê para evitar viagens à cidade. Fazia o mesmo para os indígenas se estes o necessitassem.

O outro foco de observação que ressaltam aos olhos são os aspectos da performance ritual dos nativos. Os dados observados são escritos com cuidado e se tornam valiosos como aspectos etnográficos desta etnia nos seus primeiros tempos de contato. Por exemplo, informa muitas vezes coisas do tipo: os homens chegaram com abundancia de peixes e começaram outro ritual, pois o cotidiano era feito de oração e trabalho, orat et laborat.

"Pelas quatro horas da madrugada começou o ritual que chamam (Iahinh cose + Inkama Natarene). Amanhece e param. Várias classes de flautas e cantos. Às $15 \mathrm{~h}$ começam de novo dançar e tocar as flautas e cantos, com seus penhachos típicos e pinturas de urucum. Fazem dois círculos no terreiro e de tardesinha acendem o fogo. Fazem uma parada para beber chicha, que é repartida. Reparte-se o peixe fazendo uma cerimônia, comem e dão para as famílias, depois continuam cantando e dançando, tocando várias classes de flautas. Uma turma pára de dançar às 20h, outras às 21h30. Não usam chocalho nesta dança” (09/07/77).

Quando se leem os diários fica evidente que a vida dos Enawenê Nawê é 
prioritariamente feita de rituais, em geral a vida indígena é religiosa por excelência. Por causa do Iluminismo nós perdemos esta percepção da vida humana. Além de descrever estes rituais, Cañas também chegou a gravar mais de 100 fitas que complementam ou facilitam a compreensão do que acontecia na aldeia ou nos acampamentos, contudo, não sabemos onde estão. Depois de 3 dias neste ritual, fica claro que se trata de um rito de passagem masculino:

"Pelas 3 h30 começam a dançar em duas rodas no terreiro ao redor do fogo. Vai até 6h30. É feita a passagem de um rapaz, é levado à casa das flautas, e pintado pelos homens, e vestido com suas vestes típicas, penacho e palhas, quando é vestido vai dando os outros gritos, põem-lhe a palmeirinha e é embutido o pênis. O rapaz todo pintado, mantem-se de pé em cima de uma esteira todo sério e sem falar nada, é batido com umas palhas no corpo e dando gritos, dão umas palhas penianas, é retirado da casa das flautas, pego na mão e é levado a seu pai e entregue, o pai pega as palmeiras penianas, o rapaz tira as vestimentas típicas que usam nos rituais, o rapaz mantem-se sério, conversa normalmente com os outros e fica dentro de sua casa. Pelas 8 h os homens começam a dançar no terreiro tocando a flauta de cinco canos, outra turma dentro da casa, as duas meninas de uns sete anos também dançam, que vai até 7 h20 da tarde. Como acontece comumente, várias crianças com febre." (11/07/77)

No dia seguinte os mesmos cantos e danças em duas rodas com diferentes classes de flautas. Uns levam lenha cortada aos outros em troca chicha. "Tudo com muitos gritos" (12/07/77). Começam também os trabalhos na roça e Cañas vai pescar com os Enawenê Nawê.

Começam o ritual Salumã que é também o nome de uma flautinha pequena, cantam e dançam, alguns com arco e flechas na mão, de madrugada até o clarear do dia, quando quase todas as famílias saem para fazer roça mais longe ou mais perto da aldeia:

"Saem outras famílias para fazer roça, alguns vão ficar fora de 10 a 20 dias. Os homens que ficam na aldeia vão bater timbó, voltando de tarde. O total de famílias que ficam são sete e fazem a roça para batata, cará e milho, mais perto, indo trabalhar cedo e voltando pelas 14h.” (19/07/77).

Neste momento Cañas quer organizar no Diário um pouco o relato dos rituais para esclarecer a vinculação dos mesmos com as roças de plantação de milho, batata, feijão, araruta, cará... e a pesca:

"Com o rito de Iauka, que dura uma lua, fazem as roças de mandioca, estas em comum para fazer chicha, durante a lua do mês de junho. Terminada este rito, começa o rito de Cerohy (flauta de cinco canos) este os homens, dançam... intercalando com pesca e batida de timbó, que o peixe é repartido em comum. Quando começa a lua nova, começa o rito de Salumã”.

No dia 29/08/77, Thomaz ${ }^{2}$ acrescenta no diário (16 contato): “Cai uma forte chuva e começam a plantar milho”. Thomaz continua escrevendo no diário de Cañas para indicar

\footnotetext{
${ }^{2} \mathrm{O}$ fato de Thomaz e Iasi terem acesso ao diário de Cañas e acrescentarem algo deve-se ao fato deles serem um fiel incentivador desta prática, pois Thomaz mantém até os dias de hoje este cuidado jesuítico de registrar o que acontece para a edificação do próximo.
}

134 Alois Pacini SJ. Diário de campo de um indigenista missionário. V. Cañas (1939-1987)... 130-149 
que se tratava do $17^{\circ}$ contato, em setembro, o que mostra que este trabalho era supervisionado e valorizado pelos companheiros jesuítas:

“Lua nova, começa o rito Uanorela, no qual participam todos os homens, dentro de casa e no terreiro, e dão continuação.

Rito Salumã - o dia 19 começa às 19h e vai toda a noite, dançam dentro das casas, depois até a madrugada voltam ao terreiro até clarear o dia. Bate-se timbó - e pescam - alguns vão espiar a roça de milho. Fazem dois dias que não cantam e nem dançam. Durante estes dois dias, que não cantam e nem dança, distribuem sopa de peixe, típico deles. Dia 21 de madrugada começam a dançar o rito Salumã. Repartem sopa de peixe e feijão fava, acompanhado como de costume com beiju. Param um pouco e recomeçam de novo e vai até às 18h30. Quando o sol esquenta vão dançar dentro das casas, saindo de umas e entrando nas outras. Dançaram quatro mocinhas. Nas casas dão bebidas e comida, acontecendo o mesmo ao terminar o rito. Participaram todos os homens e algumas crianças. Algumas mulheres jogavam água nos homens, durante a dança. Outra mulher unta a mão de um homem com urucu. Todos com arco e flecha nas mãos, dançaram pintados, $e$ cheios de enfeites".

No dia 23/09/77 Cañas fala da repartição do feijão fava e de uma observação etnográfica importante: "Quase todas as mulheres trabalham com algodão, fazendo redes, etc... A mulherada anda com menos trabalho do que nos meses anteriores, pois já tinham feito as bolas de beiju e seca.” Os dados a seguir indicam que Cañas escreveu depois da volta dos pescadores. Discretamente, não se inclui na maioria dos seus relatos, como um observador distanciado que cuidadosamente dá as informações que comprometem a todos:

"Saem quase todos os homens para fazer uma grande pescaria. Para o Camararé e Juruena vão dez homens, outros vão para o alto Juruena. Uma turma está disposta a ir até o Papagaio. Não conseguem com medo dos Cinta Larga. Mas essa turma de 05 conseguem passar as cachoeiras, que já conhecem e vão até a fazenda Londrina, que é saqueada por eles, levando arames, ferramentas, coradas, etc... Rebentaram o barraco que estava fechado, derramando tudo pelo chão, à procura de anzóis e ferramentas, etc..." (26/09/77)

No dia 17/12/77 os jesuítas Iasi e Thomaz chegam à aldeia e este acrescenta $20^{\circ}$ contato, uma liberdade que Cañas parece que dava para Thomaz e para Iasi, dada a amizade entre ambos.

Na imagem a seguir pode-se ver como no dia 24 e 25 de setembro temos a letra de Cañas e no dia 17 e 18/12/77, 27 e 28/01/1978 já temos a letra do Iasi, uma indicação que este encontrou o Diário do Irmão Vicente Cañas e se sentiu à vontade para acrescentar sua parte nesta história.

Depois de mais de um mês, Cañas volta a escrever a respeito de um ritual. "Dança só de homens e garotos (alguns também sem o estojo peniano) com flautas e cabaças e todos com enfeites (cf. relatório, dançam em dois círculos ao redor de uma fogueira. O cerimonial foi até às sete horas" $\left(27 / 01 / 78,21^{\circ}\right.$ contato). O cotidiano na aldeia possui também seu encanto: "No ritual desta noite houve uma novidade. Não foi oferecida a bebida (keterá), mas ao contrário colocaram-se no centro do pátio mais de 80 cabaças ou cestos com beiju (xixi) com farinha de milho. Depois de um certo tempo, recolheram este 
alimento para dentro das casas” (01/02/78).

O Diário segue com saltos de dias, pois vemos os dados acrescentados de um Relatório que provavelmente foi feito e depois transcrito para o diário de forma organizada por Thomaz Lisbôa com um desenho primoroso da localização das casas e sua organização social localizando redes armadas dentro e fora dos compartimentos de famílias nucleares, o número de pessoas de cada casa, o local onde ficava o próprio Cañas e círculos de danças, conforme dia 21 e 22/02/1978:

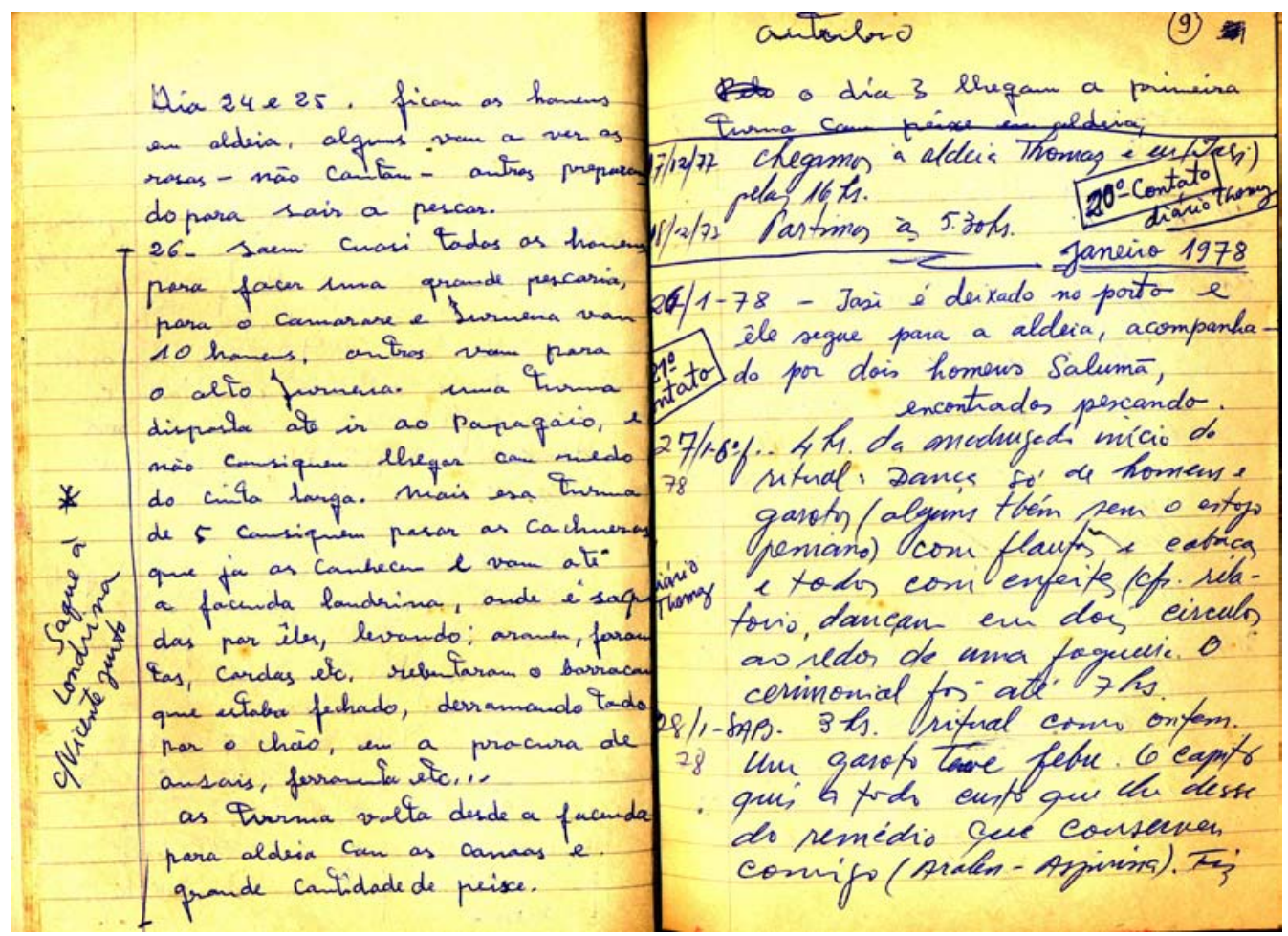




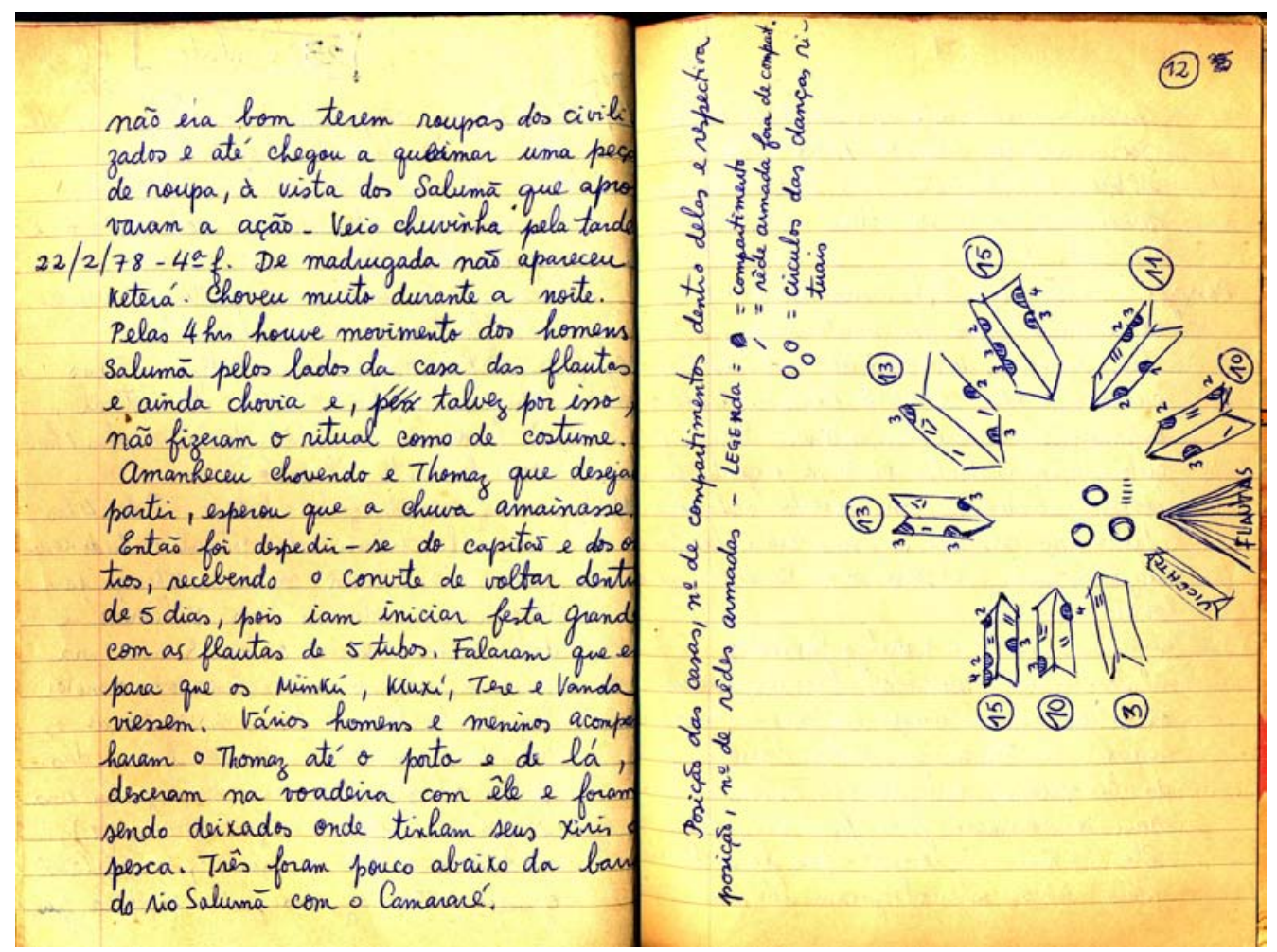

A casa e o território Enawenê Nawê ameaçados

Os saltos de dias no Diário provavelmente indicam tempos de saída da aldeia por parte de Cañas. Depois de meses, um assunto importante aparece nos diários. O esforço para captar o depoimento dos que estavam na invasão da fazenda do Domingos Tenuta, quando esta foi roubada pelos Enawenê Nawê, indica o cuidado de Cañas com os efeitos destas ações. Cañas está consciente das tensões advindas da invasão do território tradicional Enawenê Nawê, o que já trouxera conflitos sérios entre estes indígenas com outras etnias e a sociedade envolvente em geral.

Chegou também o tempo da reforma das casas: "Vão tirar buriti, alguns, outros começaram a por ripas. De tarde começou a por palhas na casa de Kaueta, e do Kauli” (16/09/79). Os detalhes são importantes como forma de compreenderem os processos dos rituais associados a estas edificações.

"Todos trabalham nas casas. Cobrem duas. As outras estão quase todas cobertas. A primeira a ser concluída é a de Kaueta. Põem cinco flautas no meio. Fazem uma dança ao redor delas, dentro da casa, os três participantes: Ualitere, Oritaka, Daduyare. Ualitere, com chocalho na mão. Saem da casa e se dirigem à casa das flautas. Inarece leva as flautas. Após a mulher de Kauetá e Sosaueri vão trazendo as casas e limpar dentro... Kauali, oferece Keterá e beiju para o pessoal. Chove de noite" (17/09/79).

Aqui Cañas se insere numa atividade de coleta do mel. Depois ele se esconde atrás das informações, como que mostrando que o mais importante são os Enawenê Nawê e o que eles fazem.

“Cedo vou tirar mel com nove homens. Voltamos pelas 3:30hs. Já tinha terminado de fazer as duas casas que faltavam. O terreiro está como ontem, cheio de tocos e 
todos ou quase todos com os pés machucados. A mulherada arranca mandioca. Os homens falam em fazer uma pescaria. Alguns arrancam minhocas. Esta noite havia muitos mosquitos. Pelas 19:15 h, Thioloce vai na festa dando uns gritos, até uns quatro ou cinco metros, além da casa do capitão para fora, atrás deles vai tocando flauta rachada, Ataina e Inarece. Os que tocam as flautas ficam no terreiro sem sair. Voltam para a casa das flautas e, chega Walytere, fala com eles e saem de novo tocando ao centro do terreiro. Ficam no centro e voltam. Deixam as flautas. Walitere vai dando uns gritos o mesmo que o Tyholoce e depois vai para sua casa. Caiu uns pau e machucou Tanana, no pé, testa e mão” (20/09/79)

Nos dias seguintes voltam a buscar mel e peixes, mas a novidade são as rãs. "Todos os homens saíram hoje, trazendo bastante mel e alguns peixes, outros trouxeram bastante rã" (21/09/79). Finalmente o terreiro cheio de restos das construções é limpo para evitar as machucaduras. Parece que o objetivo principal era a pescaria neste tempo das chuvas e tirar mel para o ritual da nova aldeia. Uma observação importante: "note-se o interessante, que ninguém fez a casa dele, outros a faziam e todos trabalhavam” (22/09/79).

Depois de uma semana, o pessoal da pescaria chega ao meio dia. "De tardezinha se reparte o peixe, no meio do terreiro. Salumã me fala que Yaukaly, esteve à minha procura, e me deixou um bilhete dizendo para eu vir que o pessoal do meio ambiente está esperando" (28/09/79).

Cañas vai ao Escondido dos Myky para combinar a infraestrutura para levar as pessoas e encaminhar as divisas da Terra Indígena Salumã, uma prioridade que Cañas sabia ser fundamental para a sobrevivência desta etnia, dado o contexto de invasão dos territórios tradicionais indígenas na região. "Falou-se da Reserva Indígena e da área Florestal” $(03 / 10 / 79)$.

"Chegada a Fontanillas. De volta a FUNAI mostrou grande interesse pela Reserva Salumã e ficando impressionado como o Salumã ocupa a área e a qualidade dos acampamentos que tem e barragens. Os limites são: margem esquerda do rio Juruena, limitando com o Juína que era área confusa. FUNAI não fala nada de ir à ladeia Salumã, para não interferir na vida dos Salumã. A FUNAI aprova o sistema de trabalho que estamos fazendo, com muito interesse para que os Salumã sejam um povo autêntico. CEMA - quer parte da terra dos Salumã para pesquisa e daí, que eles viram como os Salumã ocupam a terra. Parece que a SEMA está em ponta (litígio) com a FUNAI e aí vem a visita de ambos para limitar a área Salumã. $O$ material que trouxeram foi o necessário para fazer o levantamento.

Que ótimo que visitassem a área e tirassem conclusões para resolver o problema da terra” (09/10/79).

\section{Além dos problemas das invasões o cuidado da saúde é urgente}

Quando percebe a epidemia de gripe, procura a Terezinha Weber nos Myky para auxiliar, mas não consegue evitar as mortes:

"Continuo o tratamento e saio para a ladeia onde tem mais gente, pois já estão melhorando. Não há febre. Cheguei na aldeia e a mãe de Kayokace está dando os últimos suspiros e morre. Me dão a notícia de que morreram mais duas mulheres. Encontro a mulher do Kauly, Ataina e Sosouery em estado de coma, consumidos 
pela febre, o restante com febre. Algumas crianças e alguns homens não tem gripe. Enterram a mulher que morreu. Medico o pessoal. Três mulheres estão lutando entre a vida e a morte. Anayry faz a cova para enterrar a defunta. Kayokace não para de chorar. Tiram o filho da defunta. Colocam a defunta numa casca de árvore. A cova é de quase dois metros de profundidade" (17/10/79)

"Continuo o tratamento dos gripados. As três mulheres ainda em estado de vida ou morte, sem forças para tossir. A febre é controlada e cortada, pois todos amanhecem com febre. A pior de todas elas, a mulher de Atayna, reagiu um pouco, mas sem força para tossir. A mulher de Sosouery não está reagindo até agora. Kokore está bem fraco. Koloualo, fraca o mesmo que Tanana-Oritaka Ene, bem consumido pela febre.

Os homens que estão melhor e as mulheres, vão arrancar mandioca e tirar mel. Fazem os rituais, Salumã. Dançam dentro das casas e no terreiro, com arcos e flechas na mão e uma flautinha pequena de três canos e de dois” (18/10/79).

Cañas se preocupa com os medicamentos, mas também com a alimentação "porque estão completamente enfraquecidos e esqueléticos”. E a atuação do pajé torna-se fundamental:

"A alimentação é bebida, peixe e mel. Não tem beiju. As mandiocas estão pequenas. Caso não houvesse gripe estariam todos nos acampamentos. Mesmo assim há duas turmas fora. Uma no acampamento, onde se fez a primeira entrada, onde está a Tere. Outra está no Camararé, esperando o milho. Alimentam-se de peixe e fruta de mangaba, bebida e mel. A mulher do capitão Atayna e Sosouery, lutando entre a vida e a morte. Orytaka e Kokore estão na mesma situação. Aparecem várias crianças com febre. De tarde vomita Akairiti. O xamã tira do corpo dele um pedaço de robafo. Oferecem peixe para o pessoal. Queimam algodão e fazem oração, repartem bolinhos de algodão para defender-se do Yakayrity” (19/10/79).

Depois da noite em vigília, amanheceram melhor! Cañas é discreto em relação a sua ação, pois não quer chamar a atenção sobre si mesmo, o que corresponde à ética jesuítica, mas os testemunhos escutados são de que ele era extremamente dedicado aos indígenas quando percebia a necessidade deste trabalho e que isso não traria uma dependência incurável.

"Os gripados começam a melhorar, estão reagindo aos medicamentos. Ninguém com febre. Alguns estão bastante fracos. O ritual chamado Salumã é feito à tarde. À noite ninguém tem febre. Estão melhorando. Kaueta está esquelética. A mulher de Atayna melhora ainda está lutando entre a vida e a morte. A mulher do capitão está fraca, quase não pode andar" (20/10/79).

No dia seguinte fazem o ritual de saída para os acampamentos e Cañas percebe que estar em outros lugares com alimentação mais abundante pode ser melhor para a saúde dos Enawenê Nawê. "Os doentes vão indo como podem. Mandam-me à frente para esperar" (21/10/79).

"Ao chegar onde está a Tere, nos falam que morreu uma mulher, esposa de Ualytere, o Kauly faz o choro, pois é filha dele segundo o parentesco. Voltando com a Tere, vimos as roças de milho que já tem espigas” (26/10/79). Cañas fala do modo de vida e um detalhe do comportamento nos acampamentos que indica um certo poder hierárquico

139 Alois Pacini SJ. Diário de campo de um indigenista missionário. V. Cañas (1939-1987)... 130-149 
ou um tabu relacionado à pesca: "Pescando e tirando mel - e a vida do acampamento. Seguem o ritual de oferecer peixe. Amanhece todos os dias o pessoal calado até que o Kayoekua dá o bom dia, então todos começam a falar” (27/10/79).

"Cedo levantam o acampamento e decidem ir descendo o Juruena. Parece que todo mundo tem intenção de ir ver civilizados. Atayna e Kayly só falam de Cuiabá. Pousa-se perto da divisa de Londrina [fazenda]. Falam de ir bater timbó na lagoa do Córrego Rico, que é a desculpa para ir ver civilizados” (30/10/79).

A curiosidade dos Enawenê Nawê pelos brancos e seus costumes parece inevitável, não há como recriminar a atração pelo diferente, mas somente acompanhar para evitar incompreensões e abusos.

"Falam muito de visitar civilizados. [...] Também falam sondando minha opinião. Eles estão esperando que eu vá buscar Tere, para eles descerem até os civilizados. Atayna que antes falava por um espírito bom ficou todo o dia doente, com um pouco de febre e o barraco dele foi feito por Daduyare, Kauly, Lonece e Yanayryry" (02/11/79).

No Domingo, dia 04/11/79, recebem a visita dos Rikbaktsa que buscam taquaras para as flechas numa região próxima, ações que servem para estabelecerem suas relações de amizade e alianças.

"Pelo meio dia chegam dois avisando que os Canoeiros estão aí. De fato eram sete numa canoa, deles duas crianças, todos gripados, um deles sem poder andar e bem magro - o Salumã. Todos ao redor do doente. Ascendem fogo para o doente. $O$ Salvador não queria parar, dado à gripe, mas ficam umas duas horas com os Salumã. Os Salumã só falavam de castanha, e ficam doidos para ir com os Canoeiros".

Cañas vai sondar os Rikbaktsa e aplicar injeção contra a gripe e evitar que contaminem os Enawenê Nawê que estão fazendo pesca de barragem no rio.

"Cedo Daduyare, Atayna, Dadokuarece, Xynare e Ynarece repartem peixe. Tyholoce e Atayna são os donos de uma das barragens, estão pegando grande quantidade de lambari, os peixes são assados na casa de Tyholoce - não deixam nem as mulheres $e$ nem as crianças tocar nos peixes e se alguma criança toca chama a atenção, até hoje ninguém comeu peixe pego na barragem. [...] A barragem do Kauly e Lonece e Ynarece, Yanayryry - quem está assando os peixe é Kaualy, ninguém comeu até agora. Está chovendo muito” (06/11/79).

Só na tarde do dia seguinte é que as mulheres e as crianças podem tocar e comer os peixes. No dia 13/11/79 Ane e Cañas vão encontrar com o Padre Balduino Loebens e o Ivar Buzatto para ir aos Cinta-Largas. "Ao chegar na Barra encontramos com o Ivar que tinha vindo com o Balduino. Subimos com o Thomaz, já bom da gripe, para o Escondido. Pousamos”. Na descida para Fontanillas pousam na casa do seringueiro Vitório na margem do Juruena. No dia 15/11/79 eles seguem de ônibus e Cañas retorna para os Enawenê Nawê.

"Kaualy, ao chegar fez o choro da filha dele que morreu no acampamento de gripe. Essa mulher era a esposa de Ualytere. Pelas sete da tarde começou o rito Salumã, aquele em que tocam uma flautinha pequena de três canos. Saem cantando da porta do chefe. A mulher de Kaueka acende o fogo no terreiro. Depois as mulheres 
sustentavam o fogo. A cada estrofe que cantavam voltavam até a porta do chefe e começavam de novo outra estrofe e saíam em direção ao fogo, dançando ao redor. Terminando voltavam à casa do chefe e faziam umas quatro vezes. Reparte-se chicha de milho. Ao fim da dança o pessoal reparte peixe, da casa de um para a casa do outro" (04/12/79).

As informações são que os Enawenê Nawê estão se pintando com jenipapo e comem milho e peixe. A castanha brasileira era obtida pelo escambo com os Rikbaktsa: "Também comem castanha e bebem chicha de milho" (06/12/79). Em contexto de rituais a alimentação é sempre importante.

"Cedo fazem o ritual. Mas hoje cedo penduram umas flautas no terreiro (teyro) e experimentam as cabaças. Trazem milho. As mulheres passam quase todo o dia batendo no pilão (ritual). Tyholoce, Xynare e Kayokace fazem flautas de água. Pelas sete da tarde, Atayna que ficou na aldeia, mais os três que fizeram as flautas, fazem um ritual, dentro da casa das flautas. Kayly oferece chicha de milho. As crianças fazem petecas com palha de milho e brincam bastante” (07/12/79).

O meio de transporte na época era ainda as canoas feitas de madeira:

"Às duas e meia da madrugada começam o ritual, que é acompanhado das flautas de água, cabaças, flautas rachadas e flautas (teyro) e também chocalhos. Dividemse em três turmas. Oferecem chicha e sopa de peixe. Ao amanhecer o dia param. Deixam no terreiro as flautas penduradas. Os homens vão fazer duas canoas e as crianças fazem outra. Volta-se pelo meio dia. Chove toda a tarde. À tardezinha fazem o ritual dentro da casa das flautas. Tocam cabaças. Oferecem-se chicha e peixe. Chega parte da turma que ficava no alto Juruena. Ficam duas famílias, pois uma das moças teve a primeira menstruação" (08/12/79).

Entre os rituais, o lazer ou os jogos também se tornam importantes como formas de interação. No dia 21/12/79 Cañas chega na aldeia e fazem o jogo de futebol de cabeça com bola feita de seringa.

"Cedo as mulheres começam a tocar o pilão ritual. Aparece Ketera. Brincamos homens a bola. Faço curativos em Lonece e Oloualo. Uma menina que tem a primeira menstruação é reclusa. São feitas as tatuagens. Arruinam. Infecciona. Nasce um menino de Kayoko. De tarde põem no terreiro 04 panelas e em círculo 104 cuias de chicha. Os que oferecem a chicha são os que ficam durante o período das barragens no rio Oloinã que são: Kauly, Makakoiare, Yanaylyly e Lonece. Oferecem a chicha e fazem o discurso. Depois todos os instrumentos musicais são tocados por um instante e terminam" (22/12/79).

Apesar da aparente acolhida dos Enawenê Nawê, este personagem diferente entre eles tinha que ser localizado socialmente e seus papéis sociais reconhecidos. Nem tudo era fácil neste meio de atuação, pois as expectativas eram grandes e amplas e o lugar social do missionário indigenista estava se estabelecendo aos poucos. No dia 25/12/79 Cañas desabafa: "É uma grande chateação. Todos querem que eu vá a procurar milho de voadeira. Não vou para ninguém, nem penso ir".

"Cedo tocam o rito Salumã. Cantam ao redor do fogo ou sentados, com arco e flecha na mão e a flautinha de três canos (Salumã) pelo espaço de uma hora. Os homens vão quase todos fazer cerca, pois a queixada está comendo a mandioca. De

141 Alois Pacini SJ. Diário de campo de um indigenista missionário. V. Cañas (1939-1987)... 130-149 
tarde jogam Hayrata. Chove pancadas esparsas. De noite Atayna faz uma percorrida pelas casas e arredores, com arco e flechas na mão. O pessoal fala de Yakayryty, por fim é possesso do espírito (transe). Fala pouco. É visita do Atorenaue - pede flechas. Levam chicha e milho, que Atorenaue reparte com as pessoas. Canta Enorenaue, e o pessoal repete - Atorenaue representado por Atayna. Canta muito e quase não fala. Faz muitos gestos (mímicas). Aparece uma flautinha de quatro canos, trazida do céu, que todos tocam e é dada para Kaury - os cantos são repetidos continuamente. Atayna, possesso, às vezes está com os olhos fechados e outras abertos. O pessoal ao redor vem alegre e conversando muito. Pelas 11:15h da noite, as mulheres cantam com Atorenaue - o mesmo que com os homens. A entonação é feita por Atorenau (Atayna) e depois é repetido. Todos estão alegres, pois amanhã sairão todos da aldeia para ir procurar milho, com as famílias. Muitas pessoas estão pesteadas, com feridas, verme (Anaure e Haloualo), a criança que nasceu do Kayoko, tem todo o corpo pipocando de bolinhas e também a boca, com dificuldade de respirar. A mãe está com malária. A criança manifesta afogamento. O filho de Kokore não é tratado, pois a criança chora e não suportam o choro. A situação está entre a vida e a morte" (28/12/79).

Diante das dificuldades, parece que Cañas refaz suas forças participando dos rituais dos Enawenê Nawê.

"As mulheres começam de madrugada o Kateoko. Param ao amanhecer o dia. Preparam-se para ir embora para as roças de milho, todo o mundo. Levam a velha doente. A uns 200 metros da aldeia morre e é enterrada no caminho. Pousamos já no Camararé. A gente pesca dentro do mato, pois as águas subiram” (30/12/79).

"Fazem-se mataxi para pegar peixe. Alguns pescam, outros fazem casas, pois falam de ficar aqui até que o milho acabe e depois subir o Juruena, nas outras roças para comer milho. Muitas pessoas estão com feridas. A criança que há dias nasceu e a mãe não estão passando bem” (01/01/80). Cañas faz parte de uma instituição tradicional, segundo os índios, que supre o que eles não conseguem realizar, o cuidado dos doentes e começam a acioná-lo para estas atividades.

"Cedo preparam-se para ir embora para as roças do alto Juruena. As famílias que não fizeram casa no Camararé me pedem para levar a mulher que está passando bem mal e a criança. A viagem demora uma hora e meia. A mulher é carregada pelo marido e filho. A perna direita está bem inchada e com hematomas. A febre não desaparece. Está ficando puro osso. De tarde chega Kuxyhyu e família que fizeram parte do trajeto a pé e canoa. A mulher vem com um tumor no peito" (04/01/80).

A mulher do pajé Kayoko e a criança estão piorando e os medicamentos não fizeram efeito. Depois da meia noite do dia 06/01/80 morre a criança e é enterrada ao clarear do dia "De noite fazem um canto para a mulher doente, quem canta é Kauary e Ualytere. O canto é chamado Yanomayty. É um canto feito para os que estão morrendo.” De madrugada morre a mãe da criança. "Xalokua casou com Ualyro. Já fizeram o casamento quando desciam. Aconteceu quando a menina deixou o local de reclusão" $(19 / 01 / 80)$.

Os ciclos da vida e morte deixam quem cuida da saúde sem ação, porque nem tudo 
depende destes profissionais e a vida continua. Nasce o filho de Atayna e no dia seguinte 21/01/80, a filha de Lonece. "Arrumando milho e pescando dentro do mato. O milho é trazido pelas mulheres e é pendurado nas casas. Também debulham e estão enchendo xiris. O consumo de milho é abundante”. Parte do milho é pendurado e outra parte é desgranado em grandes xiris, para ser levado até a aldeia.

"Lonece guarda uma dieta bem rigorosa. Não sai de casa, pois é a primeira filha. Atayna, a dieta não é rigorosa, pois sai para pescar e tirar mel, etc... também já é o sétimo filho. Levam-me e me mostram onde vão construir uma nova aldeia. Vão abandonar a recém feita. A nova aldeia será feita a 20 min da barra do Camararé com o Juruena. Os mais animadas são: Kayokace e Atayna; dão desculpas de que anta, porco, gasolina - mas parece que é castanha e civilizados” (23/01/80).

\section{As pescarias coletivas}

Depois de quase um mês nas roças de milho, vão retornando para a aldeia. $\mathrm{O}$ ritmo mostra que os indígenas não são preguiçosos de modo algum. "Agora todos estão na aldeia. À tardezinha, tocam o Lerohy. Os que tocam são Kauary e Atayna. Começam tocando nas casas. Atayna leva o Ataho na mão. As vestimentas são de buriti, com uma pena de arara atrás da cabeça” (29/01/80).

Impressiona o cuidado com que Cañas descreve os rituais e como apreende com detalhes as questões das distribuições de alimentos e outros bens e serviços, uma forma clara dele indicar o que ele mais admirava na sociedade com a qual ele estava convivendo.

“Às 4 h começa o ritual Lerohy e Yalyna. [...] As duas turmas fazem o ritual dentro das casas depois que amanhece e vai até 13h os de Yalyna. Entregam os cocares a Salanece, Tyholoce fica e Atayna chamou no terreiro. Vem Atayna do Lerohy e canta um pouco no terreiro. depois os três se dirigem dentro das casas cantando $1^{a}$ casa Ualytere (sacerdote), $2^{a}$ casa Orytakaene, $3^{a}$ casa Atayna (xamã), $4^{a}$ casa Kauekua. Saem e vão ao centro do terreiro. Não tocam nenhum instrumento. Só cantam no terreiro e dentro das casas. Duração uma hora e meia e termina. Atayna volta ao Lerohy. A turma do Lerohy termina às 14 horas. Durante o dia só participam no Lerohy, Atayna, Kaury, Ualytere, Xynare e Kayeka. Terminam sem os cocares. Só com penas. No fim só tocam as flautas um bom tempo e depois cantam. Kaioko (viúvo) só participa no final, um pouco no meio do terreiro. Dão por encerrado o ritual do Lerohy e Yalyna, que durou toda a temporada do milho” (01/02/80).

Nos dias seguintes jogam ou brincam a Haybata, o futebol de cabeça. E os queixadas invadem as roças de mandioca, mas os Enawenê Nawê não caçam o porco do mato, pois não gostam de comer carne vermelha. "Kauekua está fazendo bastante sal de palmeira. Atayna (xamã) entra em transe de noite (flautas de 4 canas). Anayryry oferece beiju e macalahí" (20/02/80). Resolveram arrancar bastante mandioca para usar, pois os queixadas estavam comendo tudo. "Cheguei na aldeia e já tinham ido para o Uaty" (07/03/80), dá a impressão que uaty é o buraco para pegar os porcos. "Vão tirar mandioca. Os porcos tinha caído na armadilha. De tarde as mulheres oferecem ketera para os homens. De noite cantam as mulheres, sentadas no terreiro. Kauary, Lonece e Kaueta entoavam os cantos. O ritual durou mais ou menos uma hora” (08/03/80). Mas lendo o 
diário compreendemos que se trata da barragem, o “Uaty do rio Mutum”. Nos dias seguintes Cañas ficou com eles no acampamento e observa que tiraram cipó para pescar na barragem. Tocam as flautas as seguintes pessoas: Kayokace (flauta rachada) e Atayna (flauta de teyro). "Durante uma hora se oferece sal, até as crianças ganham sal, tudo entro do ritual” (11/03/80). "Cedo todos vamos tirar grossos cipós e paus para a barragem. Somente à tarde se retorna ao acampamento. Coloca-se na barragem o nervo central e paus em forma de $x$. Os mais ativos são: Atayna (xamã), Tyholoce e Kayokace. As crianças também ajudam. Não há toque de flautas” (12/03/80).

O esforço maior é para construir esta obra de engenharia fenomenal, fazer o "nervo central” da barragem bem travado é fundamental e Cañas observa cada detalhe:

"Tiram-se paus grossos. Atayna, com uma vara de mais ou menos um metro marca os lugares onde vai a armadilha e os lugares vão sendo repartidos. Cada um dá seu palpite e os lugares ficam para cada homem durante as pescarias. A parte central o nervo da barragem - todos ajudam agora com a repartição dos lugares. Cada qual põe seus paus em forma de rampa e um x acima. Os paus grossos são trazidos entre dois homens. Para decorar os lugares de cada um foi revisto e percorrida a barragem quatro vezes. Alguns faziam sinais com embira. Pois cada homem tem quatro a cinco lugares para armadilha ao longo da barragem que tem 30 a 40 metros de comprimento. Pelo meio dia chegam os homens que tinham ido para a aldeia levar peixe. Trazem notícias de lá, a mais falada: porco queixada comeu quase toda a mandioca. Alguns fazem mataxi” (15/03/80).

O trabalho é pesado e leva mais uma semana: paus bem grossos para as rampas no meio, de um a outro extremo; barras para colocar nas rampas onde vão os buracos para as armadilhas e também para por folhas para represar água para que o peixe não escape; palha de bacaba para tampar os buracos das barras; varetas de palha de buriti para fazer armadilhas...

"Cedo se trabalha na construção de armadilhas. As conversas destes dias são: coisas antigas como guerras... morte por Yakayryty, afogamento em construção de barragem e ausência de mulheres. Alimentação: beiju, oleniti, um ou outro peixe e mel. De tarde ficam prontas as armadilhas” (22/03/80).

As observações a respeito dos trabalhos comunitários com a dedicação de todos se mostra articulada com as necessidades de cada um, as tarefas de todos e de cada membro da comunidade ou etnia. Cada um coloca as suas armadilhas na barragem.

“Domingo. Pelo meio dia ficam prontas as armadilhas dentro da barragem. São 57 armadilhas. Voltam para casa e cada homem faz chicha. Pronta a chicha fazem um ritual. Cada um oferece ao outro o mesmo que come, o sal pelo espaço de meia hora. Hoje ninguém tira as armadilhas de dentro da água” (23/03/80).

"Cedo vamos ver as armadilhas. Não tinham peixe. Tira-se palha e alguns paus para a barragem. Esfrega-se a boca das armadilhas com folhas e barro especial. As folhas são cheirosas para atrair os peixes. Pelas $11 \mathrm{~h}$ se vai ver as armadilhas. Dentro delas haviam 63 piavas. Todos ficam alegres pois já começa a dar peixes. Antes de entrar na água, todos se esfregam com folhas que dão espuma para o peixe não assustar. Quando os peixes eram retirados das armadilhas a barragem deu um estalido em uma das pontas. Deu apenas um susto, pois não arrebentou. 
Tira-se mais paus grossos e se reforça a barragem. Este trabalho vai até às 16h. Tira-se mel de abelhas Europa. Os primeiros peixes são assados na casa de Tyholoceene. Depois fazem um pequeno ritual e são repartidos (e se quebra o tabu de não comer), pois como está dando bastante peixe, decidiram começar a comer. No ano anterior demoraram três dias para comer. Tyholoce é que comanda tudo, junto com Atayna (xamã)" (24/03/80).

São muitas as emoções e os cuidados nesta pescaria coletiva: "As barragens foram olhadas às 5h30, 11 h45 e 16 h30 horas. Levaram as quatro flautas até a barragem. Fazem queimação de Alytyoko, algodão... para afastar os espíritos maus da barragem (Yakayryty) e tudo vai indo bem. Fazem-se xiris. Foram pegas 10 piavas” (25/03/80). A pescaria é observada e denominada como uma colheita:

"Cedo 5h30, como nos demais dias, não dá peixe. Vai-se às barragens para limpar as armadilhas, pois durante a noite entram folhas. Já estão sendo assados e moqueados muitos peixes. Às $10 \mathrm{~h} 30$ encontram-se muitos peixes nas armadilhas. Pelo menos seis xiris grandes cheios de peixes - piavas e alguns tucunarés. Foram colhidos às 17h mais dois xiris de peixes" (27/03/80).

\section{$E$ a vida segue em ritmo acelerado}

O ritual do início das relações nas relações como um pedido de bênção dos filhos aos pais quando acordam foi registrado por Cañas em diferentes momentos: "Tyholoceene, Atayna (xamã), Anaure, estes mesmos sãos os que dão o bom dia" (28/03/80). E no dia seguinte Anaure dá o bom dia, o que inaugura mais um dia de atividades intensas como mostram os diários em relação ao ritmo frenético desta etnia. "A barragem é reforçada em um extremo. Ualytere faz esteira de embira para que as matrinchãs que pularem caiam nela”.

As notícias esparsas no diário são boas: "Encontro a turma de Oloyna que vem subindo, com as canoas cheias de peixe e ainda fica peixe no acampamento. A barragem deu muito peixe. A aldeia está se preparando para receber o pessoal do Oloyna” (03/04/80). "Subindo o Camararé encontro uma turma de Salumã que vai por o milho no Juruena. Vou com eles" (08/05/80). E a curiosidade com as coisas trazidas pelos Rikbaktsa impressiona: "Chegamos no acampamento e há um tumulto, pois os Canoeiros levaram vários machados, facões, enxadas, cabaças. Pousamos” (09/05/80).

No dia 13/05/80 Cañas chega na aldeia e escreve no diário as novidades: o nascimento do filho de Makakoyarene. Yalouynace; depois da primeira menstruação, a filha de Tyholocene e a filha de Kaualy, Kauytakohace, estavam reclusas; Kayoko foi morar na casa de Tyholoceene, pois casou com a sua filha; e fizeram o ritual de iniciação de Toaly.

"As duas pessoas com máscaras dançam um pouco dando gritos. Kaueka oferece chicha, Yotoxy põe a panela com chicha no terreiro. Kauekua oferece sal para as máscaras. Entram na aldeia o pessoal tocando flautas. As máscaras entram dentro da casa das flautas, juntamente com as flautas que vinham tocando. Daduyare e Kaualy estavam dentro das máscaras. Yotxy, Anaure, Ualytere, Kauekua oferecem sal. O pessoal começa a colocar os enfeites. Continuam a repartir sal. $1^{a}$ Kokore, Tyholoce, Atayna e Ynarece são os primeiros a começar a dança no terreiro e cantam em frente à casa de Ualytere e Kauekua. Do restante das casas só se 
aproximam, mas não param” (24/05/80).

Depois de ler e digitar estes diários, impressiona em Cañas o gosto pelos rituais indígenas, parece que o tempo todo ele está envolvido com estas formas de rezar. Sabe os nomes de todos e coloca quem dança nos grupos sociais e alianças na qual esta performance acontece. Isso indica o cuidado de Cañas em aprender a língua dos Enawenê Nawê, o que foi possível com cerca de ano e meio de convivência e a atenção por cada uma das pessoas, nomeando-as sempre que possível. No dia seguinte escreve: "Oferecem comida e bebida. Os homens falam através das flautas”. Para Cañas o movimento da aldeia é o ritual.

"Pelas 7h saem as duas máscaras todas enfeitadas de cocar e colares, dando gritos tipos sineta. Vão por todas as casas andando. Na casa de Orytaka param. As mulheres conversam com as duas caras. Como é natural as duas caras não conversam, só dão gritos. Oritaka oferece peixe. Ficam fazendo sua dança no terreiro perto da casa das flautas. Kauekua oferece oleniti, que vai dentro das máscaras. Daduyare e Koxyhy, as duas máscaras vão para a casa de Kaualy, permanecem um pouco e seguem para o caminho que vai à derrubada. Andam um pouco e param. Sai o pessoal e começam a desmanchar as máscaras. Com o cortejo de crianças e adultos, o pessoal vai levando a palha. São 16h30. Cada máscara tem seu nome, e mora nos morros que estão perto da Fazenda Londrina. Também alguns falam em Yakayryty, pois é nesses morros que o Yakayryty mora. Estas duas máscaras mora na ilha perto do meu barraco, onde tem a gasolina, e nos morros da fazenda Londrina o Yakayryty, dizem que dentro da água. O nome das máscaras é Eolory, onde moram muitos. As palhas das máscaras são usadas para tampar as partes das casas.

Hoje alguns homens ficam na aldeia e outros vão plantar mandioca. As mulheres quase todas foram arrancar mandioca. As crianças brincam imitando as máscaras. Koxyhy retira da casa de Atayna panelas de alocuare e beiju de milho e coloca no terreiro. Fala para Atayna e Kaualy que está pronto. Quem oferece o alocuare é o mesmo Koxyhy” (26/05/80).

Já vimos mostrando os dois aspectos complementares do dia a dia dos Enawenê Nawê que aparecem no diário: o trabalho e o ritual. Aqui voltamos a chamar a atenção para este aspecto, pois observar uma etnia em movimento como fez Cañas é algo exigente quando necessita de um cuidado respeitoso em relação à privacidade do outro. Neste caso, Cañas estava junto como um deles, o que fazia com que fossem possíveis as observações valiosas que buscamos ler com cuidado para mostrar por trás delas o homem cuidadoso e atento que dava as informações que nos dão acesso a um tesouro que estava escondido e foi-nos presenteado por este missionário indigenista.

"Os homens vão para o trabalho: plantar mandioca e prosseguir na derrubada. Ualytere, Xalokua, Daduyare e Ualytere e respectivas mulheres vão para as roças do Juruena para buscar batatas [...] O fogo do centro do terreiro é o local onde se realiza o Lerohy e o Yalyna realiza-se no outro fogo perto da casa das flautas" (28/05/80).

Como é bom poder participar destes momentos únicos e sentir-se tão próximo dele e dos Enaueneneue por causa da dedicação de Cañas em escrever! A gratidão permanece para

146 Alois Pacini SJ. Diário de campo de um indigenista missionário. V. Cañas (1939-1987)... 130-149 
sempre, pois muitos já se beneficiaram destes escritos e outros tantos se beneficiarão, principalmente aqueles que desejam colaborar e participar desta atividade missionária indigenista junto a esta etnia. Contudo, um aspecto que vale explicitar é que os maiores beneficiados deste trabalho do Diário são os próprios Enawenê Nawê. Parece que foi isso que motivou Cañas nesta árdua tarefa. Ou seja, o trabalho com os Enawenê Nawê são pautados por estes trabalhos originários de Cañas e também estes diários estão disponíveis para os próprios Enawenê Nawê a fim de terem acesso a um passado sistematizado, quando ainda não lhes era possível a escrita por eles mesmos. Apesar da escola demorar entre os Enawenê Nawê, agora esta tarefa da escrita de sua história vai passando aos poucos a eles mesmos.

"Os homens durante o dia fazem roças e plantam. A mulherada faz panelas, mandioca... ascende o fogo no terreiro (Kauekua e Yotoxi).

Quando terminam das casas vão cada um para o seu fogo. No centro do terreiro fica o fogo Lerohy e perto da casa das flautas Yalyna” (29/05/80).

O detalhe é que todo santo dia existe trabalho e oração: “Como em todos estes dias atrás, cada um vai fazer os seus trabalhos da lavoura. As mulheres fazem panelas e vão buscar mandioca” (30/05/80).

"Makakoyare, neto de Kaualy, no momento em que nasceu seu irmão, passou para a casa com seu vovô, dorme junto com ele. O menino vai para sua casa, seu pai lhe dá atenção, mas não muito - o menino faz viva pelo terreiro... os pais dele usam uma tática para o menino não sentir muito, pois ele já não é mais o centro das atenções, pois tem seu irmão menor. Em casa de seus avós, dão-lhe comida... o menino quando quer uma coisa se não dão, berra até conseguir ter o que deseja, quase sempre comida. Sua avó não é muito generosa com ele. Comigo o menino é demais, não larga do meu pé, onde vou vai atrás, onde já se viu... o menino é carinhoso e inteligente, mas eu não quero que ele transmita sua afetividade para mim. Quando o menino berra prolongadamente, o pai dele vem conferir. Sua vovó vê-se naqueles apuros" (01/06/80).

Pensar que é necessário por cerca na roça para que os porcos selvagens não invadam é uma novidade no mundo indígena, principalmente para quem já conviveu com os Rikbaktsa e Chiquitanos que não perdem uma caça: “Alguns homens estão dando os últimos retoques nas roças, pondo cerca etc... fala-se em ir buscar castanha com muita frequência. Come-se feijão fava, cará, araruta. O ketera é escasso” (20/06/80).

"Durante o Lerohy, fez-se a repartição de lenha. Alguns homens cercam as roças de mandioca, outros fazem a segunda roça de milho perto da aldeia" (21/06/80). E começam a fazer uma canoa grande: "Uns fazem canoas, outros pescam e outros ainda fazem roça de milho. Come-se bastante feijão e batata” (22/06/80). Eu estive entre os Rikbaktsa e recebemos na época a visita dos Enawenê Nawê. Quando se fala em canoa grande é porque este aspecto impressiona, pois cerca de 12 homens em pé remaram nestas canoas subindo a correnteza do Juruena em frente a Fontanillas, onde a correnteza se torna surpreendente. "Uns pescam. Outros quase terminam de fazer a canoa. Kaxayry, que estava reclusa pela $2^{a}$ menstruação, saiu ontem da reclusão. As pessoas entram no ritual aos poucos, especialmente quando terminam de rachar lenha” (23/06/80).

A vontade é mostrar toda a riqueza destes diários, mas não há tempo nem campo 
para isso. Temos que ficar na humildade e disponibilizar alguns tesouros que motivem a estudos mais aprofundados. Observemos finalmente com ele um momento desta história, três dias de pescaria:

“Às 5:30h encontram-se vários piaus e matrinxãs nas armadilhas. Colhem-se duas colmeias de mel Europa. O pessoal apanha talo de buriti e varas para assar os peixes. Às 12:30h verificam-se as armadilhas e retiram-se muitos peixes, mais de duzentos. Os miúdos dos peixes são aproveitados para comer misturados com farinha (makalahi). Os miúdos são enrolados em folhas e postos para assar. A comida é semelhante à farofa. Também preparam para levar para a aldeia. Ninguém aproveita os miúdos que colhe em sua própria armadilha, recolhe os miúdos dos peixes colhidos nas armadilhas dos outros. Um troca com o outro da mesma forma que são trocados os peixes. Ninguém como os peixes que caem nas próprias armadilhas. Às $17 \mathrm{~h}$ retiram-se muitos peixes das armadilhas. Lolame, menino, estava brincando na beira da barragem e foi puxado pelo buraco de uma das armadilhas e ficou com a cabeça dentro da água. Sorte que seu irmão Kueyroceene e outros homens vieram e puxaram o menino para fora. Foi somente um susto. De noite saem os contos (as histórias) daqueles que historicamente ficaram presos nas armadilhas, inclusive homens grandes..." (28/03/84).

Não há preguiça nem tempo ruim para fazer uma pescaria, as coisas mais necessárias entre os Enaueneneue:

“Às 5 h Kueyroceene, Laluyare e Camararê vão até a Barra para buscar cascas de árvores (matá), que não foram trazidas quando vieram, pois as canoas estavam cheias. Estas casacas destinam-se à fabricação de um maior número de armadilhas. Às 5;30h retiram-se muitos peixes das armadilhas. Às $11 \mathrm{~h}$ retiram-se uns 400 a 600 peixes sendo muitos matrinxãs. Todos os dias pela tarde busca-se lenha para assar os peixes. Dentro da casa é muito quente devido ao calor do fogo assando os peixes. Às 17h recolhe-se muito peixe” (29/03/84).

Tudo acontece com um segredo e um cuidado: as pescarias são coletivas, momentos intensos de trabalho e lazer nos quais todos sentem-se importantes e participando no sustento desta vida Enawenê Nawê:

“Às 5:30h são retirados muitos peixes das armadilhas. Pelas 8 horas chegam as três pessoas que ontem foram para a Barra do $12 \mathrm{com}$ o Camararé. Os festeiros que ficaram na aldeia são: Orytakaene, Xinare, Toaly, Kayokace, Solamenakua, Kokore (Salumã), Salokua, Kauyaloceeene. Daduyare também é festeiro, mas foi para a barragem. O pessoal que foi para a barragem do rio Mutum são: Atayna (xamã), Dedare, Anaure, Zakaka, Lonece, Yalauynaceatokue, Lalore (paralítico), Ynareceene, Ynarece, Dodouery, Walytere, Laluyare, Kueyroceene e também 7 crianças. O restante dos homens foram para o rio Olouynã com algumas crianças. Os festeiros que ficaram na aldeia farão sal, limparão o caminho que leva até o porto, procurarão milho no rio Iquê e receberão o pessoal quando retornarem das pescarias e cuidarão dos rituais que vem depois da pescaria. O pessoal que chegou com as cascas fazem novas armadilhas. Retiram-se alguns peixes das armadilhas às 11:30h, a metade do que foi coletado ontem. Às 17:30h retiram-se uns 100 peixes das armadilhas. As conversas da noite foram longas, pois contaram os casos de envenenamento pelo mesmo grupo” (30/03/84). 
Impressiona que parece que não cansava a Cañas escrever sobre os rituais, pois vão e voltam continuamente estes rituais que povoam a experiência de convivência na aldeia e nos acampamentos. Contudo, por vezes encontramos no Diário "etc e etc..." para assuntos do cotidiano, conversa fiada que começa a relatar para indicar que houve muito mais do que ele escreve, mas não tem paciência de ficar envolvido com estes detalhes, e muito menos prezo a escrever...

No final do nosso diálogo com Pivetta no dia 17/06/2015, este informou que, devido às ameaças sofridas por Cañas, este preparou um pacu assado para que Cañas não precisasse sair do ônibus para comer algo na viagem e foi com ele até o ônibus na última vez que o viu nesta viagem eternizada até os Enawenê Nawê.

Cañas tinha uma facilidade em identificar pessoas que comungavam com os ideais libertários aos quais se aliava e tinha uma crítica muito forte aos que eram coniventes com a estrutura da sociedade exploradora e injusta vinculada ao capitalismo. Classifica assim as pessoas com mais liberdade nos escritos poéticos do que nos diários que buscam explicitar sua missão profética vivendo despojadamente junto aos indígenas. Contudo, Pivetta diz que Cañas acreditava no ser humano e compreendia que as pessoas podiam mudar para melhor. O Diário encerra no dia 24/03/1987, sem saber que seu sangue seria derramado naqueles próximos dias, com um planejamento que é próprio de pessoas práticas e habilidosas:

"Os familiares mandaram mais beiju e makalahi, também batatas, milho, cará e araruta. Vou até o osso acampamento, chegando pelo meio dia. Ficarei alguns dias fazendo ordem no acampamento, trazendo algo de combustível e consertar o assoalho da Marajó (barco). Esta madeira ainda tem que ser trazida de Brasnorte".

Penso que Cañas está escondido numa descrição insistente dos rituais e das pescarias. Ao observar a quantidade de peixes ou ao saber cada um que dançou ou cantou pelo nome, temos a forma interessada desta presença na aldeia ou no acampamento para colheita ou pescaria sempre no ritmo dos Enawenê Nawê. Assim a vida intensa iniciava pela meia noite, sempre alegrando o mês indígena, e se estendia pela madrugada até o amanhecer, uma sabedoria de atividades ritualísticas nestes calores do Mato Grosso. Pelos diários podemos observar que Cañas se deliciava com as pescarias, com as comidas gostosas e com os rituais. As roças são olhadas de mais longe, mas a terra prometida estava próxima e o seu sangue derramado fecundou em flor esta parte do planeta. 